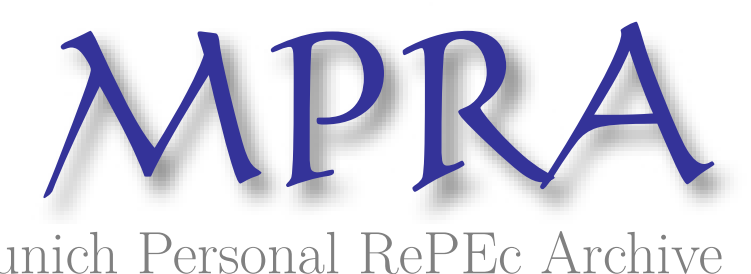

Munich Personal RePEc Archive

\title{
Corporate Governance and Disclosure Practices in India: MNC Subsidiaries versus Domestic Cross-Listed Firms
}

Sapovadia, Vrajlal and Madhani, Pankaj

20 April 2015

Online at https://mpra.ub.uni-muenchen.de/96043/

MPRA Paper No. 96043, posted 22 Oct 2019 13:28 UTC 
Corporate Governance and Disclosure Practices in India: MNC Subsidiaries versus Domestic Cross-Listed Firms

Author detail:

\begin{tabular}{|c|c|c|}
\hline Particulars & Author & Co-author \\
\hline Name & Pankaj M. Madhani & Vrajlal K. Sapovadia \\
\hline Affiliation & $\begin{array}{l}\text { Faculty ( Finance and Strategy) } \\
\text { IBS Business School, } \\
\text { IBS House, Opp. AUDA Lake } \\
\text { Science City Road, Off. S.G. Road, } \\
\text { Ahmedabad - } 380 \text { 060, India }\end{array}$ & $\begin{array}{l}\text { Executive Director, Shanti Business } \\
\text { School, Ahmedabad 380058, India }\end{array}$ \\
\hline Address & $\begin{array}{l}\text { 32, Krishna Bungalows } \\
\text { Opp. Shyam Villa - II } \\
\text { Near Gala Gymkhana } \\
\text { Bopal, Ahmedabad- } 380 \text { 058, India }\end{array}$ & $\begin{array}{l}\text { A-48 Snehdeep Society, Jivraj Park, } \\
\text { Ahmedabad 380051, India }\end{array}$ \\
\hline email & pmadhani@iit.edu & prof_sapovadia@yahoo.co.in \\
\hline & pankaj.madhani@gmail.com & dr.vrajlal.sapovadia@gmail.com \\
\hline Phone & \#91-9662122075 & \#91-79-26824501 \\
\hline
\end{tabular}




\title{
Corporate Governance and Disclosure Practices in India: MNC Subsidiaries versus Domestic Cross-Listed Firms
}

\begin{abstract}
:
This research intend to investigate empirically whether MNC subsidiaries have better corporate governance and disclosure policies compared to domestic cross-listed firms from the Indian perspectives. Using firms across different sectors listed in Bombay Stock Exchange (BSE), this research aims to analyze difference in corporate governance and disclosure practices among firms owned by foreign owner (MNC subsidiaries) and local owner (domestic cross-listed firms). The findings can shed light on the governance and disclosure practices of MNC subsidiaries and domestic cross-listed firms, in different legal institutional environments.
\end{abstract}

Several scholars have worked on the corporate governance and disclosure practices of domestic firms as well as MNCs subsidiaries listed in India. But comparisons between MNCs subsidiaries and cross-listed firms have received very little attention. The question is whether cross-listed firms listed abroad (US/Europe) will have different behavior in their disclosure policies compared to subsidiaries of MNCs. This study focuses on this direction and aims to analyze difference in corporate governance and disclosure practices among MNC subsidiaries and cross-listed firms as well as cross-listing in US versus Europe. This research indicates that subsidiaries of MNCs and cross-listed firms have statistical significant difference in corporate governance and disclosure practices. The study also found that due to different institutional and legal requirements, the domestic cross-listed firms disclose more information than MNCs subsidiaries listed only in host country. 


\section{Corporate Governance and Disclosure Practices in India: MNC Subsidiaries versus Domestic Cross-Listed Firms}

\section{Introduction}

Firms having multinational presence such as subsidiaries of Multinational Corporations (MNCs) have their parent firm in other country; have operations in more than one country and may also be listed in the host country. MNCs subsidiaries operate across different countries with different corporate governance regimes, which will often deviate from corporate governance practices in the MNC home country. As such, host country has domestic firms originated and listed in the host country as well as MNC subsidiaries, operated and listed in the same legal institutional environment. As the regulatory environment in the host country is the same for both groups i.e. domestic firms and subsidiaries of MNCs, it is possible that domestic cross-listed firms may have different corporate governance and disclosure practices as they are also governed by regulatory environment of host country. Cross-listing involves a firm that is already trading on its home country stock exchange deciding to also list on an international exchange (host country).

The question is whether firms with foreign ownerships (MNCs) have better behavior in their disclosure policies in host country compared to domestic cross-listed firms as institutional, legal and regulatory environment is different for both groups. Hence, this research intend to investigate empirically whether MNC subsidiaries have better corporate governance and disclosure policies compared to domestic cross-listed firms from the Indian perspectives. Using firms across different sectors listed in Bombay Stock Exchange (BSE), this research study aims to analyze difference in corporate governance and disclosure practices among firms owned by foreign owner (MNC subsidiaries) and local owner (domestic cross-listed firms). The findings can shed light on the governance and disclosure practices of MNC subsidiaries and domestic cross-listed firms, in different legal institutional environments.

\section{Literature Review}

Corporate governance is defined as an institutional arrangement that not only addresses the agency problem between shareholders and managers of the firm, but also provides the context for the decisions taken by the top management of the firm (Madhani, 2015). Good corporate governance is a key driver of sustainable corporate growth and long-term competitive advantage (Madhani, 2007). Firms, across the globe, recognize that there are economic benefits to be gained from a well-managed disclosure policy. This shows that firms in need of a good deal of external financing, such as rapidly growing firms, have an incentive to improve their disclosure and corporate governance. In this context, the fundamental objective of a corporate governance framework is to identify a basis for strategic co-operation between shareholders and managers of the firm such that the agency problem is reduced and a basis for decisions that promote the competitiveness of the firm is provided (Sinha, 2006). As La Porta et al., (1998) argue, good corporate governance is needed for better access to external financing at lower cost.

Prior to the adoption of Clause 49, India was considered a laggard in corporate governance practices. From 1947 (independence) through 1991, the Indian government pursued socialist policies. The government nationalized most banks, and became the principal provider of both debt and equity capital for private firms. The performance of the government agencies who provided capital to private firms was measured based on the amount of capital disbursed 
rather than return on capital investment. This policy created little incentive for managers of private firms to voluntarily adopt good governance practices. Hence, during this period (1947-1991), corporate governance practices in India, which was considered to be comparable to that of British firms at independence, considerably deteriorated in spite of multiple legal checks through various legislation applicable to listed companies (Sapovadia, 2011). In the year 1992, the Securities and Exchange Board of India (SEBI) - India's securities market regulator was formed. By the mid-1990s, the Indian economy was growing steadily, and Indian firms began to seek capital from variety of sources to finance expansion into the global market spaces created by liberalization and the growth of outsourcing (Black and Khanna, 2007).

The need for capital by Indian firms, amongst other things, led to corporate governance reforms. The first major step in this area was setting up of the Confederations of Indian Industry (CII) Code for Desirable Corporate Governance in 1998 (Sanan, 2011). The code published in April 1998 comprised seventeen recommendations. A year later, in May 1999, SEBI announced the formation of the Kumar Mangalam Birla committee, which was tasked with proposing corporate governance reforms. These reforms became 'Clause 49' so named because they were implemented through a new Clause 49, which was added to stock exchange listing requirements. Clause 49 has both mandatory as well as voluntary provisions. Mandatory provisions relate to board composition, audit committees, board procedures, management discussion and analysis in the annual reports, certification of financial statements and internal controls, and corporate governance reporting. The adoption of Clause 49 was viewed as a turning point in Indian corporate governance (Black and Khanna, 2007). Dharmapala and Khanna (2013) report that small Indian firms which are subject to Clause 49 react positively to plans by SEBI to enforce the Clause 49, relative to similar firms not subject to Clause 49.

Several studies examine Indian corporate governance generally. Khanna (2008) reviews the development of corporate governance norms in India beginning from independence era. World Bank (2005), Sarkar and Sarkar (2000), and Mohanty (2003) examine how firm-level governance influences the behaviour of institutional investors, or vice-versa. Mohanty (2003) finds that institutional investors own a higher percentage of the shares of better-governed Indian firms. This is consistent with research in other countries (Aggarwal et al., 2005; Ferreira and Matos, 2008). Bhattacharyya and Rao (2004) examine whether adoption of Clause 49 (an important set of governance reforms in India) predicts lower volatility and returns for large Indian firms. Black and Khanna (2007) conduct an event study of the adoption of Clause 49 and report positive returns to a treatment group of large firms (who were required to comply quickly) relative to small firms (for whom compliance was delayed). Implementation of Clause 49 in India was done staggered manner, with large firms (included in "Group A" on the BSE) required to comply first, followed by medium-sized firms and then small firms.

Some research studies have shown that with increased corporate disclosure, firms experience a reduction in cost of equity capital (Botosan and Plumlee, 2002), as well as, the cost of debt (Sengupta, 1998). Similarly, Healy et al., (1999) found a beneficial increase in the firm's stock liquidity and performance. Moreover, information disclosure in itself is a strategic tool, which enhances a company's ability to raise capital at the lowest possible cost (Lev, 1992). Information disclosure plays an important role in protecting investors' rights and wealth. There is a long-standing assumption that stronger corporate governance is conducive to higher quality accounting information (Dey, 2005), and it follows that the market will react 
favorably to better quality accounting reporting. Beekes and Brown (2006) studied Australian firms to investigate the association between corporate governance quality and the flow of information. They found that firms with better corporate governance make more informative disclosures.

MNCs are seen as amongst the world's most powerful types of organizations as they account for a large share of intellectual property rights (IPRs), are big employers and contribute to the economic development of the foreign countries where they operate (Williams, 2009). Firms having multinational presence such as subsidiaries of MNCs have their parent firm i.e. MNC in other country, have operations in more than one country and may also be listed in the host country.

MNCs as a parent firm pressurize their subsidiaries internally to adopt their organizational practices which are transferred to it from their parent firm in home country. A MNC subsidiary is defined as a local affiliate of a MNC located in a foreign country of which the parent company holds majority ownership in promoters' holding (Bouquet and Birkinshaw, 2008). Externally the host country institutional environment pressurizes MNC subsidiaries to adopt local organizational practices. Hence, MNCs subsidiary has to decide which institutional pressures are more important; internal pressures that would enable it to become legitimate within the working environment of MNCs or the external pressures that would enable it to gain external legitimacy within the legal environment of the host country. In contrast, domestic firms need to confirm only to the demands of their domestic rules, regulations and stakeholder expectations (Alpay et al., 2005).

MNCs subsidiaries face additional complexities and challenges in corporate governance and disclosure practices due to the diversity of corporate governance rules, regulations and stakeholder expectations in the various host countries in which they operate (Luo, 2005). MNCs subsidiaries operate across different countries with different corporate governance regimes, which will often deviate from corporate governance practices in the MNC home country. MNCs have to thus manage multiple economic, legal, political and cultural environments externally as well as complex networks of knowledge and resource flows internally (Volkmar, 2003). Such subsidiaries of MNCs are influenced by the parent firm in home country to a great extent. As such, host country has domestic firms originated and listed in the host country as well as MNC subsidiaries, operated and listed in the same legal institutional environment. As the regulatory environment in the host country is the same for both groups i.e. domestic firms and subsidiaries of MNCs, it is possible that subsidiaries of MNCs internalise some aspects of disclosure practices of their parent company and hence exhibit better governance and disclosure practices compared to domestic firms.

Prior research applied institutional theory to the study of MNCs (Westney, 2005), especially to identify and study factors influencing MNC subsidiary practices in different host country institutional environments (Kostova and Roth, 2002; Tempel et al., 2006). Empirical research has found that institutional pressures created by legal environment develops an institutional context within which firms make decisions regarding what to disclose and how (Crawford and Williams, 2010). Institutional theory can also be linked to legitimacy theory, as their combined view could provide a better explanation of disclosure practices of MNC subsidiaries. The application of legitimacy theory to MNCs has been studied in detail by many researchers (Dacin et al., 2008; Kostova and Zaheer, 1999). They assert that a MNC subsidiary has to gain dual legitimacy and as such is in a state of institutional duality. Some 
studies have examined the differences in corporate disclosure practices between MNC corporate headquarters and domestic firms (Krigger, 1988; Leksel and Lindgren, 1982).

Global presence of MNC and its subsidiaries creates a demand for voluntary disclosure by such firms because MNC subsidiaries are likely to have greater information asymmetry as a result of their greater scope and complexity. Such effect will be larger for firms based in countries with weak legal environments than for firms based in countries with strong legal institutional environments. Hence, it is expected that the subsidiaries of MNCs will provide more disclosures as a result of weak legal environment at host country. Accordingly, MNC subsidiaries are expected to have higher corporate governance and disclosure level compared to domestic firms in India. Pattnaik and Gray (2012) found evidence for such hypothesis in Indian environment and empirically proved that subsidiaries of MNCs were more transparent and disclose more information than domestic listed Indian firms.

Globalization could also affect level of disclosure by globally exposed firms because of firm complexity. That is, global firms may disclose more because they have more complex operations or financing arrangements that require greater disclosure. Firms may disclose more as globalization increases because more exposure to the capital, product, or labour markets increases the demand for better disclosure. Khanna, et al., (2004) analyzed the disclosure practices of firms as a function of their interaction with US markets for a group of 794 firms from 24 countries in the Asia-Pacific and Europe. Researchers found positive and significant correlation between these disclosure scores and US listing. They found that non US firms interacting with the US product, capital and labour markets are more likely to use disclosure practices similar to those in the US as their involvement with US markets increases.

Cross-listing is the process by which a publicly held firm lists its stocks on a stock exchange beyond its national boundaries and hence it refers to the situation whereby a firm lists its stock on an overseas exchange (Peng and Blevins, 2012; Shi et al., 2012). Cross-listing in the US leads to increased disclosure, this is associated with increased legitimacy from the perspective of analysts. The capital market is not the only market that may affect a multinational firm's disclosure policy. Instead, product market and labour market forces also can exert pressure on firms to increase disclosures even in the absence of capital market forces (Khanna et al., 2004).

According to Karolyi (2012), over 3000 foreign firms have been cross-listed on over 40 major stock exchanges. Major stock exchanges of the world such as New York Stock Exchange (NYSE), NASDAQ, London Stock Exchange (LSE), and London's Alternative Investment Market (AIM) have attracted significant cross-listings of firms. Also, NYSE Euronext (Europe), Deutsche Börse, Hong Kong, and Singapore have all become popular cross-listing destinations for firms. Most foreign firms cross-list in the foreign markets via depositary receipts. According to the Citi depositary receipts market analysis, in 2011 trading volumes of depositary receipts reached 170.7 billion shares compared to 148.3 billion shares in 2010, showing increase in volume by 22.4 billion shares. Mainly dominated by firms from BRIC countries (Brazil, Russia, India, and China), capital raised by cross-listed firms totalled $\$ 16.6$ billion (Peng and Su, 2014).

Cross-listed firms face two conflicting pressures in global business environment. They face two institutional environments viz. the external environment of host country where stock is originally cross-listed and the internal environment of home country where stock is originally 
listed. Cross-listed firms need to confirm to the laws, values and norms of the overseas host country in which they are listed as well as home country in which they operate. Hence, it is possible that cross-listed firms exhibit higher level of corporate governance and disclosure. Madhani (2014), studied Indian firms listed in Bombay Stock Exchange (BSE) and found that cross-listed firms have better corporate governance and disclosure practices compared to domestic firms listed only in India.

Prior research study has found substantial cross-country differences related to corporate governance (La Porta et al., 1999) and disclosure (Bushman et al., 2004) practices by firms. Listing status of firms can also be an important factor in explaining variability in the extent of corporate governance and disclosure. Cooke (1989a) in an analysis of Swedish firms found that disclosure in the corporate annual reports of domestically listed firms was significantly lower than that reported by multiple listed firms. According to Lang et al., (2003a), non US firms that are cross-listed in the US stock exchanges have earnings properties that are more like US firms compared to other firms in their home countries. They also found that crosslisting of firms in the US increases the coverage by US analysts and such firms are less likely to manage earnings and are more likely to have earnings that are timely and conservative.

There are many motives why firms may cross-list their stocks on foreign markets. Benefits of cross-listings can be segregated in various themes so as to give rise of many hypotheses for cross-listing of firms such as market segmentation, information asymmetry, recognition visibility, liquidity, branding, legitimacy, signaling theory and prestige hypotheses (Madhani, 2014). The benefits of cross-listing involve both financial and informational benefits that result from overcoming market segmentation and reducing informational asymmetries (Karolyi, 1998). Empirical studies demonstrate that stronger disclosure practices of a firm are associated with many benefits such as decreases in its bid ask-spread (Leuz and Verrecchia, 2000), cost of capital (Botosan, 1997) and cost of debt (Sengupta, 1998) and increases in its stock liquidity and analyst following (Healy et al., 1999). Lang et al., (2004) find that crosslisted firms have more accurate analyst coverage.

Firms listed overseas are exposed to greater agency problems. Consequently, voluntary disclosure by such firms reduces the monitoring costs of shareholders. Voluntary disclosure can also be associated with a capital-needs hypothesis; as such firms with objective of raising capital in foreign markets at the lowest possible cost of capital (Cooke, 1989b) are likely to increase disclosure voluntarily. Cross-listed firms from weak investor protection countries experience higher stock returns surrounding the listing (Foerster and Karolyi, 1999), relatively higher valuation (Doidge et al., 2004), more access to external finance (Lins et al., 2005), and lower cost of capital (Hail and Leuz, 2009). Firms voluntarily choose to cross-list in the US market because the enhanced investor protection through cross-listings helps to reduce agency costs (Reese and Weisbach, 2002). Lang et al., (2003a) report an increase in the number of analysts and forecast accuracy indicating an increase in the level of information environment of foreign firms cross-listed in the US. Lang et al., (2003b) find that cross-listed firms have a better accounting quality in the pre cross-listed period and improvement in the post cross-listed period.

The decision of a firm to cross-list its stock, has been found to be driven by various economic concerns (Nair and Skaggs, 2012). These include accessing capital from more liquid markets (Lins et al., 2005), widening and deepening the investor base (Jithendranathan et al., 2000), capitalizing on more favorable macro environments (Loughran and Ritter, 1995), reputational bonding (Siegel, 2005, 2009) and benefiting from a post-listing stock premium (Doidge et al., 
2004). Cross-listing generally predicts an increase in share price. Cross-listings of firms lower the cost of capital as they expand a firm's shareholder base, spreading the firm's risk over a greater number of investors who, in turn, demand a smaller premium. Errunza and Miller (2000) document a $42 \%$ decline in the cost of capital by cross-listing.

Baker et al., (2002) found that cross-listing in the US and UK increases the visibility and information distribution of firms as demonstrated by the increase in the number of analysts and media coverage and a decrease in the cost of equity capital after the cross-listing. There are also domestic benefits for firms that cross-list their stocks on overseas exchanges. Puthenpurackal (2006) found that domestic investors also bestow additional legitimacy on firms that cross-list, which can help them gain performance in domestic markets also. Crosslisting of firms certainly has formal components (such as fulfilling of all formal listing requirements), as well as the informal components - the stronger reputation, the enhanced familiarity for both the cross-listed firm to know the host-country stakeholders and for the host-country stakeholders to know the cross-listed firm (Bell et al., 2012).

Cross-listing can force firms from countries with poor investor protection to enhance the corporate governance by bonding a firm to increased accounting disclosure and hence reducing the risk of exploitation by insiders. Thus, firms from emerging markets can reduce their agency costs for external financing by subjecting themselves to more stringent standards and enforcement in developed markets (Stulz, 1999). When firms cross-list on a developed market, the disclosure behavior of firms attracts more scrutiny and thereby yields a significant increase in the quantity and quality of firms' disclosures as they are subject to increased disclosure requirements (Coffee, 1999).

The stricter corporate governance practices increase corporate disclosures. Jaggi and Low (2000) analyze the impact of legal systems on disclosures and find that higher levels of disclosure are exhibited by firms from common law countries than by firms from civil law countries. Hope (2003a) uses a larger and more representative sample of countries and finds that both legal origin and culture contribute to explaining corporate disclosure.

There is an expanding literature that examines whether a country's legal and judicial institutions affect disclosures practices across countries (Jaggi and Low, 2000). Bushman et al., (2004) studied corporate transparency across 45 countries and found substantial differences in corporate disclosure practices that arose from a country's legal as well as judicial regime. Researchers such as Hope (2003b), and Francis et al., (2005) also found that country-level institutional factors matter in explaining disclosure levels. However, for the most part, these studies do not consider how globally exposed firm's disclosures are affected by the legal and institutional environment of the host country i.e., they ignore the fact that MNC subsidiaries are listed in host country as well as many firms raised funds by crosslisting in multiple countries.

Despite prior research on the corporate governance and disclosure practices of MNCs subsidiaries as well as cross-listed firms with reference to domestic firms, comparisons between MNCs subsidiaries and cross-listed firms have received very little attention. The question is whether cross-listed firms listed abroad (US/Europe) will have better behavior in their disclosure policies compared to subsidiaries of MNCs. This study focuses on this direction and aims to analyze difference in corporate governance and disclosure practices among MNC subsidiaries and cross-listed firms as well as cross-listing in US versus Europe. 


\section{Development of Hypotheses}

Legal institutional environment of MNC subsidiaries, operated and listed in the host country (i.e. in India) will be different from that of domestic firms cross-listed in developed countries (i.e. in US/Europe). As subsidiaries of MNCs as well as cross-listed firms are globally exposed in multiple institutional environments that require different disclosure rules, they have better disclosure. As the regulatory environment in the host country is different for both the groups i.e. cross-listed firms and subsidiaries of MNCs, it is possible that their corporate governance and disclosure practices are different although they have higher standard of corporate governance and disclosure compared to domestic listed firms.

\section{MNCs Subsidiaries}

Compared to domestic firms, subsidiaries of MNCs operating in developing countries are expected to have higher standard of corporate governance and disclose more information and observe better reporting practices for the various reasons explained below:

1) As they have to comply with the regulations of not only their host country but also the parent country or home country, where accounting practices and standards of reporting are substantially higher.

2) Usually, these firms are equipped with more advanced accounting software tools and packages, efficient audit staff, competent and efficient accounting and support staff, and better management practices. The variety of information collected by the parent firms i.e. MNCs, along with their better reporting systems can result in the increase of voluntary disclosures. Hence, they have the potential to disclose more information without any incremental processing costs on disclosures (Choi and Mueller, 1996).

3) These firms are under closer scrutiny of various political and pressure groups within the host country, as they view them as sources of economic exploitation and agents of imperialist power (Kamran and Nicholls, 1994). Hence, such firms have an incentive to disclose more information in order to avert any pressure for excessive control for exploitation (Srinivasan, 2008).

4) MNCs have two related levels of corporate governance structures - one at headquarters and other at subsidiary levels. In the case of MNCs with subsidiaries listed on local stock exchanges in different host countries, those subsidiaries need to simultaneously conform to the host country's legal requirements as well governance practices of the MNC in home country (Kiel et al., 2006). Therefore, MNC subsidiaries face dual pressures, from the demand of the host country environment where they are operated and also from corporate headquarters of parent MNC in home country (Rosenzweig and Singh, 1991).

\section{Cross-listed Firms}

Similarly, cross-listed firms listed in US/Europe are expected to have higher standard of corporate governance and disclose practices compared to domestic firms for the various reasons explained below:

1) Cross-listed firms will have a higher level of disclosure and disclose more information, if the requirements of overseas stock markets are greater than those of their domestic stock exchanges. An important driver of this increase appears to be compliance by cross-listed firms with stricter disclosure rules (Reese and Weisbach, 2002). Cross-listing on the US/Europe regulated exchanges requires the firm to fully or partially reconcile to the US/UK, International Accounting Standards (IAS) and 
Generally Accepted Accounting Principles (GAAP) and hence provide a certain level of mandatory disclosure that exceeds the level required by its home market.

2) Doidge et al., (2010) found that firms in countries with weak securities law benefit from bonding to a country with stronger securities law. The bonding hypothesis suggests that domestic firms can bypass their countries' weak legal institutions by listing on a foreign exchange such as major US/Europe exchange and thus become subject to US/Europe market's superior corporate governance system and more stringent investor protection regulations. Cross-listed firms in the US/Europe have to abide by the more stringent rules set by capital market and stock exchange regulators (legal bonding). Listing in prestigious markets such as US and Europe can also be used by a firm to provide signals to stakeholders about a firm's adoption of good governance practices. As a result, cross-listed firms should have better corporate governance than non-cross-listed firms from the same country.

3) Emerging market firms would have a greater need to enhance their legitimacy through mechanisms such as cross-listing than their developed market counterparts, as they may not have the same access to institutions that their developed market counterparts may have (Drogendijk and Hadjikhani, 2008; Roth and Kostova, 2003).

4) Domestic firms typically adopt the corporate governance practices of their home country where they are listed and operated. Cross-listed firms are expected to have higher standard of corporate governance and disclose more information and observe better reporting practices as they have to comply with the regulations of not only their home country but also the host country, where accounting practices and standards of reporting are substantially higher.

5) Cross-listed firms are more transparent compared to firms which are listed only in the home market. This is because the information asymmetry arising from overseas listing increases the incentives for cross-listed firms listed in foreign exchanges of US/Europe to disclose information at a higher level. Domestic firms listed overseas adopt the standard disclosure rules of host country (US/Europe), which is usually more stringent than the disclosure practices of the home country i.e. India.

6) Moreover, with the additional disclosure, domestic cross-listed firms improve the information environment in their home country also. In the scenario, where corporate governance codes are weak in home country, especially in terms of enforcement and punitive power, domestic firms do not have any incentives to disclose more. This suggests that the host country's legal environment have a positive impact on the quality of voluntary disclosures. Thus, compared to domestic firms listed only in home country, cross-listed firms listed overseas have stronger disclosure practices.

This study focuses on corporate governance and disclosure practices of MNC subsidiaries and cross-listed firms from Indian stock market to study whether there are significant differences in their practices.

\section{Listing Requirements in US}

Foreign firms that list on US exchanges have to register with the Securities and Exchange Commission (SEC) and become subject to US securities laws. These laws not only increase disclosure and financial reporting requirements, but also reduce agency costs and restrain controlling shareholders by imposing substantive obligations on them. US cross-listed firms are worth more - there is a "cross-listing premium" (Doidge et al., 2004). Oxelheim and Randoy (2003) suggest that foreign exchange listing signals a firm's commitment to the higher disclosure standards prevailing in the market in which it lists as such firms have had to meet disclosure requirements of two countries - the host country and new country of listing. 
The Sarbanes-Oxley (SOX) Act, 2002 has made US listings significantly less attractive to foreign companies as SOX makes a US listing more rigorous because it imposes severe costs on companies and their managers, especially through the compliance requirements of Section 404, which aims to reduce the market impact of accounting "errors" from fraud, inadvertent misstatements, or omissions, by assuring effective management controls over reporting and which, in turn, creates significant legal exposures for companies as well as for managers (Doidge et al., 2007).

\section{Listing Requirements in Europe}

In London, firms can list on the Main Market as a Depositary Receipt (DR) or ordinary issue or they can list on the Alternative Investment Market. There are different requirements for each listing type. Firms that list as ordinary issues must be admitted to listing by the UK Listing Authority (UKLA), part of the Financial Services Authority (FSA), and then be admitted to trading by the London Stock Exchange (LSE). Most foreign firms that list as ordinary issues in London seek a "secondary" listing (the "primary listing" being the home market - foreign firms typically do not incorporate in the UK). In general, the provisions of the UKLA's listing rules that seek to protect minority investors do not apply to foreign firms with a secondary listing (Coffee, 2007).

As the Combined Code on Corporate Governance applies only to companies incorporated in the UK, firms with foreign listings are not required to comply with the code. Moreover, these firms are not required to explain why they have chosen not to comply. The main requirement for firms with ordinary listings on the Main Market is to file financial information prepared in accordance with UK or US GAAP or International Accounting Standards (IAS), although exceptions are made to this requirement in some cases. Firms with foreign listings in London generally need only comply with the governance rules of their home country. Hence, firms with foreign listings in London are subject to a "light touch" approach to regulation (Doidge et al., 2007).

\section{Testable Hypotheses}

This research study seeks to examine how MNC subsidiaries and cross-listed firms differ in corporate governance and disclosure practices. As mentioned above, globally exposed firms such as MNC subsidiaries and cross-listed firms show higher standard of corporate governance and disclosure practices compared to domestic listed firms. Also, cross-listing in developed countries, requires better governance practices and disclosure for cross-listed firms. Thus, based on this argument, following alternate hypothesis is proposed:

$\mathrm{H} 1_{01}$ :

Corporate governance and disclosure practices of domestic cross-listed firms listed in US/Europe are higher than those of MNC subsidiaries listed only in India.

This study also explores the degree of strength for institutional environment by comparing institutional environment of US versus Europe. As mentioned above, US regulatory and institutional environment is much stronger than regulatory and institutional environment of Europe. Therefore, based on this argument, following alternate hypothesis is proposed:

$\mathrm{H} 1_{02}$ :

Corporate governance and disclosure practices of domestic cross-listed firms listed in US are higher than those listed in Europe. 


\section{Research Design and Methodology}

Objectives of the Study

1. To measure overall corporate governance and disclosure practices of MNC subsidiaries and cross-listed firms with the help of an appropriate instrument as an evaluation tool.

2. To know that to what extent MNC subsidiaries and cross-listed firms disclosed through their annual reports by measuring Corporate Governance and Disclosure (CGD) scores of MNC subsidiaries and cross-listed firms.

3. To understand that to what extent cross-listed firms in US and Europe are different in their corporate governance and disclosure practices.

Scope of the Study

This study will help us to understand that whether cross-listed firms have better corporate governance and disclosure practices compared to MNC subsidiaries or vice versa in Indian context. It also identifies whether US listed firms disclose more compared to Europe listed firms.

\section{Sources of Data}

For the purpose of study, data of the sample firms collected from the annual reports of the same for the financial year 2011-12 (for the period ending March 2012 or December 2012 based on the firms' financial year) have been downloaded from the CMIE PROWESS database (Version 4.14).

\section{Sampling Technique Applied}

Stratified sampling was used for obtaining data of firms listed in BSE and is constituent of S\&P BSE sectoral indices.

\section{Sampling and Data Collection}

The sample for the study was collected from the firms listed in BSE in the form of S\&P BSE sector indices. Sectoral indices at BSE aim to represent minimum of $90 \%$ of the free-float market capitalization for sectoral firms from the universe of S\&P BSE 500 index. This sector index consists of the firms classified in that particular sector of the BSE 500 index.

From these eleven sectors, banking sector (Bankex) was eliminated as the disclosure requirements for these firms are specialized and regulated by other regulatory authorities. Likewise, realty sector was also not considered because of specific issues of governance such as lack of transparency in financial transactions, valuations of land and properties. Also, majority of companies in these sectors are in the unorganized sectors. Hence, remaining all nine sectors from S\&P BSE sectoral indices were studied for this research. In each of these sectors, top six firms as per market capitalization are selected for sample.

The CGD score of firms was calculated by thoroughly scrutinizing annual report of sample of firms with the help of instrument developed by Subramanian and Reddy (2012). Out of sample of 54 firms, 12 firms are MNC subsidiaries; while remaining 42 firms are domestic firms. Out of these 42 firms, 26 are domestic firms listed only in India. As this study focuses on MNC subsidiaries and cross-listed firms, domestic firms listed only in India are excluded from our study; hence, making our sample size to 28. Hence, out of pool 28 firms, 12 firms are MNCs subsidiaries and 16 firms are cross-listed. 
The sample firms represent different sectors viz.: Auto (11.1\%), Metal (11.1\%), Oil \& Gas (11.1\%), Consumer Durables (11.1\%), Capital Goods (11.1\%), FMCG (11.1\%), Health Care (11.1\%), IT (11.1\%), and Power (11.1\%). As shown below in Table 1, these 54 firms selected from 9 different sectors represent $91 \%$ of overall sectoral index weight. Hence, these samples of 54 firms truly represent selected 9 sectors.

Table 1: Weight of Sample Firms in their respective Sectoral Indices

\begin{tabular}{|c|l|c|c|}
\hline $\begin{array}{c}\text { Sr. } \\
\text { No. }\end{array}$ & S\&P BSE Sectoral Indices & $\begin{array}{c}\text { No. of } \\
\text { Firms } \\
\text { Studied }\end{array}$ & $\begin{array}{c}\text { Weight in } \\
\text { Index } \\
\text { (Per Cent) }\end{array}$ \\
\hline $\mathbf{1}$ & S\&P BSE IT & 6 & 95 \\
\hline $\mathbf{2}$ & S\&P BSE Healthcare & 6 & 88 \\
\hline $\mathbf{3}$ & S\&P BSE Oil \& Gas & 6 & 94 \\
\hline $\mathbf{4}$ & S\&P BSE FMCG & 6 & 91 \\
\hline $\mathbf{5}$ & S\&P BSE Auto & 6 & 89 \\
\hline $\mathbf{6}$ & S\&P BSE Power & 6 & 97 \\
\hline $\mathbf{7}$ & S\&P BSE Capital Goods & 6 & 94 \\
\hline $\mathbf{8}$ & S\&P BSE Metal & 6 & 92 \\
\hline $\mathbf{9}$ & S\&P BSE Consumer Durables & $\mathbf{5 4}$ & $\mathbf{9 1}$ \\
\hline & Total Sample Size & & \\
\hline
\end{tabular}

(Source: Calculated form BSE Web Site)

The Research Instrument: Measurement of Corporate Governance Disclosure Score

Researchers have used various methods of computing disclosure score for determining the level of disclosures. The disclosure index provides a reasonable method for measuring the overall disclosure quality of a firm. Prior research in this area has made extensive use of such index methodology as a research tool (Marston and Shrives, 1991). Index method involves the development of an extensive list of disclosure items, which are expected to be relevant to the users of information.

This research study use a voluntary disclosure index based on Subramanian and Reddy (2012) and hand-collect governance and disclosure data for final sample of 28 firms. In this research study, the CGD score of subsidiaries of MNCs as well as cross-listed firms listed in BSE were measured by doing content analysis of annual report of sample firms. One point is awarded when information on an item is disclosed and zero otherwise. All items in the instrument were given equal weight, and the scores thus arrived at (for each category), with a higher score indicating greater disclosure. Final corporate governance and disclosure score (Maximum: 67) for each firm was calculated by adding overall score received in ownership (Maximum: 19) as well as and board category (Maximum: 48) (See Annexure - I).

\section{Data Analysis and Interpretation}

For the purpose of this study, the firms have been taken from nine different sectors for making meaningful comparison of MNCs subsidiaries and cross-listed firms. The reason behind this classification is to find out the extent of disclosure in MNCs subsidiaries and cross-listed firms. The study aims to find out if CGD scores of MNCs subsidiaries and crosslisted firms are significantly different. In the research sample of 28 firms, 12 firms belong to MNCs subsidiaries while 16 firms are cross-listed (Table 2). 
Table 2: MNCs subsidiaries and Cross-listed Firms according to Sectors

\begin{tabular}{|c|l|c|c|c|}
\hline $\begin{array}{c}\text { Sr. } \\
\text { No. }\end{array}$ & \multicolumn{1}{|c|}{ Sector } & $\begin{array}{c}\text { MNC } \\
\text { Subsidiaries }\end{array}$ & $\begin{array}{c}\text { Cross-listed } \\
\text { Firms }\end{array}$ & Total \\
\hline $\mathbf{1}$ & IT & 1 & 2 & 3 \\
\hline $\mathbf{2}$ & Health Care & 2 & 2 & 4 \\
\hline $\mathbf{3}$ & Oil \& Gas & 1 & 1 & 2 \\
\hline $\mathbf{4}$ & FMCG & 3 & 2 & 5 \\
\hline $\mathbf{5}$ & Auto & 2 & 2 & 4 \\
\hline $\mathbf{6}$ & Power & - & 2 & 2 \\
\hline $\mathbf{7}$ & Capital Goods & 1 & 2 & 4 \\
\hline $\mathbf{8}$ & Metal & - & 2 & 3 \\
\hline $\mathbf{9}$ & Consumer Durables & $\mathbf{1 2}$ & $\mathbf{1 6}$ & $\mathbf{2 8}$ \\
\hline & Total & & $($ Sourc \\
\hline
\end{tabular}

(Source: Tabulated by author)

Table 3, below shows sector, MNC home country and CGD score for MNC subsidiaries.

Table 3: MNC Subsidiaries: Sector and Home Country Details

\begin{tabular}{|c|c|c|c|c|c|c|}
\hline $\begin{array}{l}\text { Sr. } \\
\text { No. }\end{array}$ & MNC Subsidiary & Sector & \begin{tabular}{|c|} 
MNC Parent \\
Country \\
(Home \\
Country) \\
\end{tabular} & $\begin{array}{c}\text { Overseas } \\
\text { Listing }\end{array}$ & $\begin{array}{l}\text { CGD } \\
\text { Score }\end{array}$ & $\begin{array}{l}\text { Mean } \\
\text { CGD } \\
\text { Score } \\
\end{array}$ \\
\hline 1 & \begin{tabular}{|l} 
Oracle Financial \\
Services Software \\
\end{tabular} & IT & US & - & 20 & 20 \\
\hline 2 & $\mathrm{ABB}$ & $\begin{array}{l}\text { Capital } \\
\text { Goods }\end{array}$ & Switzerland & - & 22 & \multirow{2}{*}{25} \\
\hline 3 & Siemens & $\begin{array}{l}\text { Capital } \\
\text { Goods }\end{array}$ & Germany & - & 28 & \\
\hline 4 & $\begin{array}{l}\text { Sterlite Industries } \\
\text { (India) }\end{array}$ & Metal & UK & US & 30 & 30 \\
\hline 5 & Maruti Suzuki & Auto & Japan & - & 19 & \multirow{2}{*}{16} \\
\hline 6 & Cummins India & Auto & US & - & 13 & \\
\hline 7 & Cairn India & Oil \& Gas & UK & - & 30 & 30 \\
\hline 8 & Hindustan Unilever & FMCG & UK & - & 33 & \multirow{3}{*}{21.33} \\
\hline 9 & $\begin{array}{l}\text { Colgate-Palmolive } \\
\text { (India) }\end{array}$ & FMCG & US & - & 15 & \\
\hline 10 & Nestle India & FMCG & Switzerland & - & 16 & \\
\hline 11 & $\begin{array}{l}\text { GlaxoSmithKline } \\
\text { Pharmaceuticals }\end{array}$ & $\begin{array}{l}\text { Health } \\
\text { Care }\end{array}$ & UK & - & 20 & \multirow{2}{*}{21} \\
\hline 12 & Ranbaxy & $\begin{array}{l}\text { Health } \\
\text { Care }\end{array}$ & Japan & Europe & 22 & \\
\hline & \multicolumn{5}{|c|}{ Overall Sector CGD Score } & 22.33 \\
\hline
\end{tabular}


(Source: Computed by author from company annual reports by applying Research Instrument)

Table 4, below shows key statistics of CGD score for MNC subsidiaries.

Table 4: MNC Subsidiaries: Key Sector and Statistics

\begin{tabular}{|c|c|c|c|c|c|c|c|c|}
\hline \multirow{2}{*}{$\begin{array}{l}\text { Sr. } \\
\text { No. }\end{array}$} & \multirow{2}{*}{ Sector } & \multirow{2}{*}{$\begin{array}{l}\text { No. of } \\
\text { Firms }\end{array}$} & \multicolumn{3}{|c|}{ CGD Score } & \multirow{2}{*}{$\begin{array}{l}\text { Mean } \\
\text { CGD } \\
\text { Score }\end{array}$} & \multirow{2}{*}{$\begin{array}{c}\text { Std. } \\
\text { Deviation }\end{array}$} & \multirow{2}{*}{$\begin{array}{l}\text { CV* } \\
(\%)\end{array}$} \\
\hline & & & Min. & Max. & Range & & & \\
\hline 1 & IT & 1 & 20 & 20 & 0 & 20 & - & - \\
\hline 2 & Capital Goods & 2 & 22 & 28 & 6 & 25 & 4.24 & 16.97 \\
\hline 3 & Metal & 1 & 30 & 30 & 0 & 30 & - & - \\
\hline 4 & Auto & 2 & 13 & 19 & 6 & 16 & 4.24 & 26.52 \\
\hline 5 & Oil \& Gas & 1 & 30 & 30 & 0 & 30 & - & - \\
\hline 6 & FMCG & 3 & 15 & 33 & 18 & 21.33 & 10.12 & 47.42 \\
\hline 7 & Health Care & 2 & 20 & 22 & 2 & 21 & 1.41 & 6.73 \\
\hline & Overall & 12 & 13 & 33 & 20 & 22.33 & 6.513 & 29.16 \\
\hline
\end{tabular}

$* \mathrm{CV}=$ Coefficient of Variation

(Source: Calculated by author)

As MNC subsidiaries such as Sterlite and Ranbaxy are cross-listed (Table 4), they are excluded from our study. Table 5, below shows key statistics of CGD score for MNC subsidiaries listed only in India.

Table 5: MNC Subsidiaries Listed only in India: Key Sector and Statistics

\begin{tabular}{|c|l|c|c|c|c|c|c|c|}
\hline \multirow{2}{*}{$\begin{array}{c}\text { Sr. } \\
\text { No. }\end{array}$} & \multirow{2}{*}{ Sector } & \multirow{2}{*}{$\begin{array}{c}\text { No. of } \\
\text { Firms }\end{array}$} & Min. & Max. & Range & $\begin{array}{c}\text { Mean } \\
\text { CGD } \\
\text { Score }\end{array}$ & $\begin{array}{c}\text { CGtd. } \\
\text { Deviation }\end{array}$ & $\begin{array}{c}\text { CV* } \\
(\%)\end{array}$ \\
\hline $\mathbf{1}$ & IT & 1 & 20 & 20 & 0 & 20 & - & - \\
\hline $\mathbf{2}$ & Capital Goods & 2 & 22 & 28 & 6 & 25 & 4.24 & 16.97 \\
\hline $\mathbf{3}$ & Auto & 2 & 13 & 19 & 6 & 16 & 4.24 & 26.52 \\
\hline $\mathbf{4}$ & Oil \& Gas & 1 & 30 & 30 & 0 & 30 & - & - \\
\hline $\mathbf{5}$ & FMCG & 3 & 15 & 33 & 18 & 21.33 & 10.12 & 47.42 \\
\hline $\mathbf{6}$ & Health Care & 1 & 20 & 20 & 0 & 20 & - & - \\
\hline & Overall & $\mathbf{1 0}$ & $\mathbf{1 3}$ & $\mathbf{3 3}$ & $\mathbf{2 0}$ & $\mathbf{2 2 . 0 6}$ & $\mathbf{6 . 6 9}$ & $\mathbf{3 0 . 9 6}$ \\
\hline
\end{tabular}

$* \mathrm{CV}=$ Coefficient of Variation

(Source: Calculated by author)

Table 6, below shows sector, overseas listing details and CGD score for cross-listed firms. 
Table 6: Cross-Listed Firms: Sector and Listing Details

\begin{tabular}{|c|c|c|c|c|c|}
\hline $\begin{array}{l}\text { Sr. } \\
\text { No. }\end{array}$ & $\begin{array}{l}\text { Cross-Listed } \\
\text { Firms }\end{array}$ & Sector & $\begin{array}{c}\text { Overseas } \\
\text { Listing } \\
\text { (Host } \\
\text { Country) }\end{array}$ & $\begin{array}{l}\text { CGD } \\
\text { Score }\end{array}$ & $\begin{array}{c}\text { Mean } \\
\text { CGD } \\
\text { Score }\end{array}$ \\
\hline 1 & Infosys & IT & US & 37 & \multirow[t]{2}{*}{42} \\
\hline 2 & Wipro & IT & US & 47 & \\
\hline 3 & Dr. Reddy & Health Care & US & 40 & \multirow[t]{2}{*}{27} \\
\hline 4 & Cipla & Health Care & Europe & 14 & \\
\hline 5 & Reliance Industries & Oil \& Gas & Europe & 34 & 34 \\
\hline 6 & ITC & FMCG & Europe & 41 & \multirow[t]{2}{*}{32.5} \\
\hline 7 & United Spirits & FMCG & Europe & 24 & \\
\hline 8 & $\begin{array}{l}\text { Mahindra \& } \\
\text { Mahindra }\end{array}$ & Auto & Europe & 30 & \multirow[t]{2}{*}{32} \\
\hline 9 & Tata Motors & Auto & $\begin{array}{l}\text { US \& } \\
\text { Europe }\end{array}$ & 34 & \\
\hline 10 & $\begin{array}{l}\text { Reliance } \\
\text { Infrastructure }\end{array}$ & Power & Europe & 30 & \multirow[t]{2}{*}{29.5} \\
\hline 11 & Tata Power & Power & Europe & 29 & \\
\hline 12 & $\mathrm{~L} \& \mathrm{~T}$ & Capital Goods & Europe & 31 & \multirow[t]{2}{*}{27} \\
\hline 13 & Crompton Greaves & Capital Goods & Europe & 23 & \\
\hline 14 & Hindalco & Metal & Europe & 20 & \multirow[t]{2}{*}{26} \\
\hline 15 & Tata Steel & Metal & Europe & 32 & \\
\hline 16 & Videocon & $\begin{array}{c}\text { Consumer } \\
\text { Durables }\end{array}$ & Europe & 18 & 18 \\
\hline \multicolumn{5}{|c|}{ Overall Sector CGD Score } & 30.25 \\
\hline
\end{tabular}

(Source: Table developed by author)

Table 7, below shows key sector statistics of CGD score for cross-listed firms.

Table 7: Cross-Listed Firms: Key Sector and Statistics

\begin{tabular}{|c|l|c|c|c|c|c|c|c|}
\hline \multirow{2}{*}{$\begin{array}{c}\text { Sr. } \\
\text { No. }\end{array}$} & \multirow{2}{*}{ Sector } & \multirow{2}{*}{$\begin{array}{c}\text { No. of } \\
\text { Firms }\end{array}$} & Min. & Max. & Range & $\begin{array}{c}\text { Cean } \\
\text { CGD } \\
\text { Score }\end{array}$ & $\begin{array}{c}\text { CGD Score } \\
\text { Deviation }\end{array}$ & $\begin{array}{c}\text { CV* } \\
(\%)\end{array}$ \\
\hline $\mathbf{1}$ & IT & 2 & 37 & 47 & 10 & 42 & 7.07 & 16.84 \\
\hline $\mathbf{2}$ & Health Care & 2 & 14 & 40 & 26 & 27 & 18.38 & 68.09 \\
\hline $\mathbf{3}$ & Oil \& Gas & 1 & 34 & 34 & 0 & 34 & - & - \\
\hline $\mathbf{4}$ & FMCG & 2 & 24 & 41 & 17 & 32.50 & 8.56 & 26.33 \\
\hline $\mathbf{5}$ & Auto & 2 & 30 & 34 & 4 & 32 & 2.83 & 8.84 \\
\hline $\mathbf{6}$ & Power & 2 & 29 & 30 & 1 & 29.5 & 0.71 & 2.40 \\
\hline $\mathbf{7}$ & Capital Goods & 2 & 23 & 31 & 8 & 27 & 5.66 & 20.95 \\
\hline
\end{tabular}




\begin{tabular}{|c|l|c|c|c|c|c|c|c|}
\hline $\mathbf{8}$ & Metal & 2 & 20 & 32 & 12 & 26 & 8.49 & 32.64 \\
\hline $\mathbf{9}$ & $\begin{array}{l}\text { Consumer } \\
\text { Durables }\end{array}$ & 1 & 18 & 18 & 0 & 18 & - & - \\
\hline & Overall & $\mathbf{1 6}$ & $\mathbf{1 4}$ & $\mathbf{4 7}$ & $\mathbf{3 3}$ & 30.25 & 8.87 & 29.33 \\
\hline
\end{tabular}

$* \mathrm{CV}=$ Coefficient of Variation

(Source: Table developed by author)

\section{Research Procedures for Testing Hypotheses}

This research conducted an inferential statistical analysis for testing the hypotheses. In order to test the significant differences in the CGD scores of domestic firms and cross-listed firms, parametric $t$-test was used.

Summary of Findings and Empirical Results

Table 8, below shows key statistics of CGD score for MNCs subsidiaries and cross-listed firms.

Table 8: MNCs Subsidiaries and Cross-listed Firms: Key Statistics

\begin{tabular}{|c|l|c|c|c|c|c|c|c|}
\hline & \multirow{2}{*}{$\begin{array}{c}\text { Sr. } \\
\text { No. }\end{array}$} & Type of Firms & $\begin{array}{c}\text { No. of } \\
\text { Firms }\end{array}$ & \multicolumn{2}{|c|}{ CGD Score } & $\begin{array}{c}\text { Mean } \\
\text { CGD } \\
\text { Score }\end{array}$ & $\begin{array}{c}\text { Std. } \\
\text { Deviation }\end{array}$ & $\begin{array}{c}\text { CV* } \\
(\%)\end{array}$ \\
\hline $\mathbf{1}$ & $\begin{array}{l}\text { MNCs } \\
\text { Subsidiaries }\end{array}$ & 10 & 13 & 33 & 20 & 21.60 & 6.69 & 30.96 \\
\hline $\mathbf{2}$ & $\begin{array}{l}\text { Cross-listed } \\
\text { Firms }\end{array}$ & 16 & 14 & 47 & 33 & 30.25 & 8.87 & 29.33 \\
\hline $\mathbf{3}$ & Total & $\mathbf{2 6}$ & $\mathbf{1 3}$ & $\mathbf{4 7}$ & $\mathbf{3 4}$ & $\mathbf{2 6 . 9 2}$ & $\mathbf{9 . 0 4}$ & $\mathbf{3 3 . 5 8}$ \\
\hline
\end{tabular}

$* \mathrm{CV}=$ Coefficient of Variation

(Source: Table developed by author)

Values of minimum, maximum, mean and standard deviation of CGD score for MNCs subsidiaries and cross-listed firms have also been reflected. Results show that there is a difference between mean and standard deviation of CGD score for MNCs subsidiaries and cross-listed firms. Analysis of the result shown in Table 8 indicates that mean of CGD score is higher for cross-listed firms at 30.25. Also, the standard deviation of CGD score is higher at 8.87 for cross-listed firms when compared to MNCs subsidiaries in the sample.

$\mathrm{HO}_{1}$ : There are no differences in corporate governance and disclosure practices of MNC subsidiaries listed only in India and domestic cross-listed firms.

The hypotheses have been tested using the univariate $t$-test. Group statistics and independent sample test output is given in Table 9 and Table 10 respectively. 
Table 9: Group Statistics for MNCs subsidiaries and Cross-listed Firms

\begin{tabular}{|c|c|c|c|c|c|}
\hline \multicolumn{6}{|c|}{ Group Statistics } \\
\hline \multicolumn{2}{|c|}{ Type of Firm } & $\begin{array}{l}\text { No. of } \\
\text { Firms }\end{array}$ & Mean & $\begin{array}{c}\text { Std. } \\
\text { Deviation }\end{array}$ & Std. \\
\hline \multirow{2}{*}{$\begin{array}{l}\text { CGD } \\
\text { Score }\end{array}$} & $\begin{array}{c}\text { MNC } \\
\text { Subsidiaries }\end{array}$ & 10 & 21.6000 & 6.68664 & 2.11450 \\
\hline & $\begin{array}{c}\text { Cross-listed } \\
\text { Firms }\end{array}$ & 16 & 30.2500 & 8.87318 & 2.21830 \\
\hline & Source: & & tho & ith SPSS & \\
\hline
\end{tabular}

Table 10: Independent Samples Test

\begin{tabular}{|c|c|c|c|c|c|c|c|c|c|}
\hline \multirow{3}{*}{$\begin{array}{l}\text { CGD } \\
\text { Score }\end{array}$} & \multicolumn{2}{|c|}{$\begin{array}{l}\text { Levene's } \\
\text { Test for } \\
\text { Equality of } \\
\text { Variances }\end{array}$} & \multicolumn{7}{|c|}{ t-test for Equality of Means } \\
\hline & \multirow[t]{2}{*}{$\mathbf{F}$} & \multirow[t]{2}{*}{ Sig. } & \multirow[t]{2}{*}{$\mathbf{t}$} & \multirow[t]{2}{*}{ df } & \multirow[t]{2}{*}{$\begin{array}{l}\text { Sig. (2- } \\
\text { tailed) }\end{array}$} & \multirow[t]{2}{*}{$\begin{array}{c}\text { Mean } \\
\text { Difference }\end{array}$} & \multirow{2}{*}{$\begin{array}{c}\text { Std. } \\
\text { Error } \\
\text { Differen } \\
\text { ce }\end{array}$} & \multicolumn{2}{|c|}{$\begin{array}{l}\text { 95\% Confidence } \\
\text { Interval of the } \\
\text { Difference }\end{array}$} \\
\hline & & & & & & & & Lower & Upper \\
\hline $\begin{array}{l}\text { Equal } \\
\text { variances } \\
\text { assumed }\end{array}$ & .529 & .474 & -2.642 & 24 & .014 & -8.65000 & 3.27428 & -15.40779 & -1.89221 \\
\hline $\begin{array}{l}\text { Equal } \\
\text { variances } \\
\text { not } \\
\text { assumed }\end{array}$ & & & -2.823 & 22.998 & .010 & -8.65000 & 3.06463 & -14.98970 & -2.31030 \\
\hline & & & Sourc & сотри & by al & with $S F$ & 20 & & \\
\hline
\end{tabular}

Table 11, shows result of univariate test.

Table 11: Results of Univariate Test

\begin{tabular}{|l|c|c|}
\hline \multicolumn{1}{|c|}{ Null Hypothesis } & $\begin{array}{c}t \text { - } \\
\text { Value }\end{array}$ & $\begin{array}{c}\text { Significance } \\
\text { Level }\end{array}$ \\
\hline $\begin{array}{l}\text { No significant difference in CGD scores of } \\
\text { MNCs subsidiaries and cross-listed firms }\end{array}$ & -2.642 & .014 \\
\hline \multicolumn{2}{|c|}{ Source: Computed by author with SPSS 20 } \\
\hline
\end{tabular}


Mean score of MNCs subsidiaries listed in India and domestic firms cross-listed in US/Europe are different with MNCs subsidiaries having CGD scores of 21.60 while crosslisted firms having scores of 30.25. Results of parametric test, as indicated in Table 11, show that significance value $p$ is less than 0.05 , therefore at $5 \%$ level of significance; null hypothesis of equality of means is rejected. Thus, there exists statistically significant difference between corporate governance and disclosure practices of MNCs subsidiaries and cross-listed firms and as such corporate governance and disclosure practices of cross-listed firms are higher than MNCs subsidiaries. The difference is significant as firms in both categories have different regulatory environment based on their place of listing and as such cross-listing requirements of domestic firms in US/Europe are much stringent compared to listing requirements in India.

$\mathrm{HO}_{2}$ : There are no differences in corporate governance and disclosure practices of domestic firms cross-listed in US and Europe.

This hypothesis studies whether corporate governance and disclosure practices between domestic firms listed in US and Europe are different. As Tata Motors is cross-listed in both US as well as Europe, it is excluded from testing of this hypothesis. Hence, there are 15 firms in this category from overall sample with 3 firms listed in US while remaining 12 firms are listed in Europe. Group statistics and independent sample test output is given in Table 12 and Table 13 respectively.

Table 12: Group Statistics for Domestic Firms Listed in US and in Europe

\begin{tabular}{|c|c|c|c|c|c|}
\hline \multicolumn{7}{|c|}{ Group Statistics } \\
\hline $\begin{array}{c}\text { Cross-Listed } \\
\text { Firms }\end{array}$ & $\begin{array}{c}\text { No. of } \\
\text { Firms }\end{array}$ & Mean & $\begin{array}{c}\text { Std. } \\
\text { Deviation }\end{array}$ & $\begin{array}{c}\text { Std. Error } \\
\text { Mean }\end{array}$ \\
\hline $\begin{array}{c}\text { CGD } \\
\text { Score }\end{array}$ & US & 3 & 41.3330 & 5.13160 & 2.96273 \\
\cline { 2 - 6 } & Europe & 12 & 27.1667 & 7.57788 & 2.18755 \\
\hline
\end{tabular}

(Source: SPSS 20 output) 
Table 13: Independent Samples Test

\begin{tabular}{|c|c|c|c|c|c|c|c|c|c|}
\hline \multirow{3}{*}{$\begin{array}{l}\text { CGD } \\
\text { Score }\end{array}$} & \multicolumn{2}{|c|}{$\begin{array}{c}\text { Levene's } \\
\text { Test for } \\
\text { Equality of } \\
\text { Variances } \\
\end{array}$} & \multicolumn{7}{|c|}{ t-test for Equality of Means } \\
\hline & \multirow[t]{2}{*}{$\mathbf{F}$} & \multirow[t]{2}{*}{ Sig. } & \multirow[t]{2}{*}{$\mathbf{t}$} & \multirow[t]{2}{*}{ df } & \multirow[t]{2}{*}{$\begin{array}{l}\text { Sig. (2- } \\
\text { tailed) }\end{array}$} & \multirow[t]{2}{*}{$\begin{array}{c}\text { Mean } \\
\text { Difference }\end{array}$} & \multirow{2}{*}{$\begin{array}{c}\text { Std. } \\
\text { Error } \\
\text { Difference }\end{array}$} & \multicolumn{2}{|c|}{$\begin{array}{l}\text { 95\% Confidence } \\
\text { Interval of the } \\
\text { Difference }\end{array}$} \\
\hline & & & & & & & & Lower & Upper \\
\hline $\begin{array}{l}\text { Equal } \\
\text { variances } \\
\text { assumed } \\
\end{array}$ & .919 & .355 & 3.025 & 13 & .010 & 14.16667 & 4.68335 & 4.04891 & 24.28443 \\
\hline $\begin{array}{l}\text { Equal } \\
\text { variances } \\
\text { not } \\
\text { assumed }\end{array}$ & & & 3.847 & 4.530 & .015 & 14.16667 & 3.68282 & 4.39669 & 23.93664 \\
\hline
\end{tabular}

(Source: SPSS 20 output)

Table 14, shows result of univariate test.

Table 14: Results of Univariate Test

\begin{tabular}{|l|c|c|}
\hline \multicolumn{1}{|c|}{ Null Hypothesis } & $\begin{array}{c}\boldsymbol{t} \text { - } \\
\text { Value }\end{array}$ & $\begin{array}{c}\text { Significance } \\
\text { Level }\end{array}$ \\
\hline $\begin{array}{l}\text { No significant difference in CGD scores of } \\
\text { Indian firms cross-listed in US and Europe. }\end{array}$ & 3.02 & .010 \\
\hline
\end{tabular}

(Source: SPSS 20 output)

Mean score of domestic firms listed in US and firms listed in Europe are different with firms listed in US having CGD scores of 41.33 while firms listed in Europe having scores of 27.16. Results, as indicated in Table 14, show that significance value $p$ is less than 0.05 , therefore at $5 \%$ level of significance; null hypothesis of equality of means is rejected. Thus, there exists statistically significant difference between corporate governance and disclosure practices among domestic firms listed in US and Europe as such practices of domestic firms crosslisted in US is higher than firms listed in Europe. The difference is significant as firms in both categories have different regulatory environment based on their place of listing and as such US listing requirements are much stringent compared to listing requirement of firms in Europe.

\section{Discussion and Research Implications}

Prior research findings suggest that MNCs subsidiaries and cross-listed firms have higher corporate governance and disclosure level, compared to domestic firms. This research study seeks to identify whether corporate governance and disclosure practices of MNCs subsidiaries and cross-listed firms are significantly different, by studying sample of firms from Indian stock market, comprising MNCs subsidiaries listed in India as well as crosslisted firms listed in US/Europe. The research also looks into institutional, legal and regulatory environment of US and Europe from the perspectives of corporate governance and disclosure practices, to study whether they are significantly different for firms listed in those 
countries. The research findings can shed light on the governance and disclosure practices of MNC subsidiaries and cross-listed firms, in legal institutional environment of India versus US/Europe.

This research offers a new angle to explore how firms interact with different institutional environments and found that there is a significant relationship between corporate governance and disclosure practices of firms and the legal environment of country. Although, subsidiaries of MNCs disclose more compared to domestic firms, their practices are not compatible with those of their parent MNCs usually located in developed countries with a strong legal environment. As such not so strong institutional environment of host country may influence corporate governance and disclosure practices of MNCs subsidiaries. Hence, this research found that corporate governance and disclosure practices of MNCs subsidiaries are weaker than such practices of cross-listed firms. Similarly, this research found that corporate governance and disclosure practices of domestic firms listed in US are better than such practices of firms listed in Europe. It is because, institutional and legal environments of US and Europe is different with US is having higher standard of corporate governance and disclosure compared to Europe. Hence, this research supports bonding hypothesis as a driver for higher corporate governance and disclosure practices of cross-listed firms.

This study contributes to several areas of research:

1. This research contributes to an emerging line of research that examines the governance and disclosure practices of firms exposed to global markets.

2. The main contribution of this study is that it examines whether the interaction between globalization and legal institutional environment affects governance and disclosures by MNCs subsidiaries and cross-listed firms.

3. This research adds to the emerging literature that uses country-level institutional features, such as legal origin to explain cross-country differences in governance and disclosure practices.

4. This research examines how disclosure practices of MNC subsidiaries' and crosslisted firms are affected by the legal environment of host country where it's listed when compared to domestic firms.

5. This research contributes to the growing literature on MNCs subsidiaries, cross-listing of firms as well as India specific research.

In conclusion, this research found that institutional and legal environment of US and Europe is quite stronger compared to institutional and legal environment of India. Also, institutional and legal environment of Europe is weaker compared to such environment of US.

\section{Limitations of Study}

This research focuses on institutional environment of India, where MNC subsidiaries and domestic firms are listed and institutional environment of US/Europe where domestic firms are cross-listed. To get bigger picture, future research may focus on multiple institutional environment of various countries. Although sample size for this research is not too big, it fairly represents sectoral indices of BSE. Lastly as this study analyses data of sample firms for the financial year 2011-12 only, future study may be conducted with more current or multiple year panel data.

\section{Conclusions}

This research indicates that subsidiaries of MNCs and cross-listed firms have statistical significant difference in corporate governance and disclosure practices. The study also found 
that domestic cross-listed firms disclose more information than MNCs subsidiaries listed only in host country. It is because of quite different institutional and legal environment for MNC subsidiaries listed in India, compared to listing environment of US/Europe where domestic firms are cross-listed. This research concludes that country has a major role in shaping corporate governance and disclosure practices of MNC subsidiaries as well as cross-listed firms. Hence, cross-listed firms have better corporate governance and disclosure practices compared to MNC subsidiaries listed only in India. Also, institutional, legal and regulatory environment of US is much stronger compared to Europe and hence US cross-listed firms display higher standard of corporate governance and disclosure practices compared to Europe. The research provides insight regarding the question of how a country's institutional, legal and regulatory environment may influence the effectiveness of firm-level corporate governance mechanisms. This study may be of interest to regulators, policy makers and practitioners that are considering the implementation of additional mandatory requirements to improve investor protections or corporate governance. 
ANNEXURE - I

Instrument for Measuring CGD Score of Sample Firms

\begin{tabular}{|c|c|c|}
\hline \multirow{2}{*}{$\begin{array}{c}\text { Component } \\
1:\end{array}$} & \multicolumn{2}{|r|}{ Board and Management Structure and Process } \\
\hline & $\begin{array}{l}\text { Sr. } \\
\text { No. }\end{array}$ & Disclosure of: \\
\hline & 1 & Details about current employment/position of directors provided? \\
\hline & 2 & Details about previous employment/positions provided? \\
\hline & 3 & When each of the directors joined the board? \\
\hline & 4 & $\begin{array}{l}\text { Details about whether the chairman is executive or non- } \\
\text { executive? }\end{array}$ \\
\hline & 5 & $\begin{array}{l}\text { Detail about the chairman (other than name and executive } \\
\text { status)? }\end{array}$ \\
\hline & 6 & Details about the role of the board of directors in the company? \\
\hline & 7 & Are the dates of board meetings disclosed? \\
\hline & 8 & Is the aggregate board attendance disclosed for each meeting? \\
\hline & 9 & Are directors attending over 60 per cent of the board meetings? \\
\hline & 10 & $\begin{array}{l}\text { Are attendance details of individual directors at board } \\
\text { meetings disclosed? }\end{array}$ \\
\hline & 11 & Do independent directors constitute at least $1 / 3$ of the board? \\
\hline & 12 & Do independent directors constitute more than $1 / 2$ of the board? \\
\hline & 13 & Do independent directors constitute more than $2 / 3$ of the board? \\
\hline & 14 & A list of matters reserved for the board? \\
\hline & 15 & Is the list of audit committee (AC) members disclosed? \\
\hline & 16 & Is the majority of AC independent? \\
\hline & 17 & Is the chairman of the AC independent? \\
\hline & 18 & Is disclosure made of the basis of selection of AC members? \\
\hline & 19 & Is the aggregate attendance of AC meetings disclosed? \\
\hline & 20 & $\begin{array}{l}\text { Is the attendance of individual directors at AC meeting } \\
\text { disclosed? }\end{array}$ \\
\hline & 21 & Does the company have a remuneration committee? \\
\hline & 22 & Is the list of remuneration committee members? \\
\hline & 23 & Is the majority of RC independent? \\
\hline & 24 & $\begin{array}{l}\text { Is the remuneration committee chaired by an independent } \\
\text { director? }\end{array}$ \\
\hline & 25 & Is the frequency of RC meetings disclosed? \\
\hline \multirow[t]{9}{*}{$\begin{array}{c}\text { Component } \\
2:\end{array}$} & \multicolumn{2}{|r|}{ Board and Management Structure and Process } \\
\hline & $\begin{array}{l}\text { Sr. } \\
\text { No. }\end{array}$ & Disclosure of: \\
\hline & $\begin{array}{l}26 \\
27\end{array}$ & $\begin{array}{l}\text { Is the aggregate } \mathrm{RC} \text { meeting attendance disclosed? } \\
\text { Is disclosure made of individual members' attendance in RC } \\
\text { meetings? }\end{array}$ \\
\hline & 28 & Does the company have a nominating committee? \\
\hline & 29 & Is the list of members of the nominating committee disclosed? \\
\hline & 30 & Is the majority of nominating committee independent? \\
\hline & 31 & Is the frequency of NC meetings disclosed? \\
\hline & 32 & The existence of a strategy/investment/finance committee? \\
\hline & 33 & The number of shares in the company held by directors? \\
\hline
\end{tabular}




\begin{tabular}{|c|c|c|}
\hline & $\begin{array}{l}42 \\
43 \\
44 \\
45 \\
46 \\
47 \\
48\end{array}$ & $\begin{array}{l}\text { A review of the last board meeting disclosed (for example, } \\
\text { minutes)? } \\
\text { Whether they provide director training? } \\
\text { The decision-making process of directors' pay? } \\
\text { The specifics on performance-related pay for directors? } \\
\text { Is individual performance of board members evaluated? } \\
\text { Is appraisal of board performance conducted? } \\
\text { The decision making of managers' (not Board) pay? } \\
\text { The specifics of managers' (not on Board) pay (for example, } \\
\text { salary levels and so on)? } \\
\text { The forms of managers' (not on Board) pay? } \\
\text { The specifics on performance-related pay for managers? } \\
\text { The list of the senior managers (not on the Board of Directors)? } \\
\text { The backgrounds of senior managers disclosed? } \\
\text { The details of the CEO's contract disclosed? } \\
\text { The number of shares held by the senior managers disclosed? } \\
\text { The number of shares held in other affiliated companies by } \\
\text { managers? }\end{array}$ \\
\hline \multirow{3}{*}{$\begin{array}{c}\text { Component } \\
\text { 3: }\end{array}$} & \multicolumn{2}{|r|}{ Ownership Structure and Investor Relations } \\
\hline & $\begin{array}{l}\text { Sr. } \\
\text { No. }\end{array}$ & Does the annual report contain? \\
\hline & $\begin{array}{l}1 \\
2 \\
3 \\
4 \\
5 \\
6 \\
7\end{array}$ & $\begin{array}{l}\text { Top } 1 \text { shareholder? } \\
\text { Top } 3 \text { shareholders? } \\
\text { Top } 5 \text { shareholders? } \\
\text { Top } 10 \text { shareholders? } \\
\text { Description of share classes provided? } \\
\text { Review of shareholders by type? } \\
\text { Number and identity of shareholders holding more than } 3 \text { per } \\
\text { cent? } \\
\text { Number and identity of shareholders holding more than } 5 \text { per } \\
\text { cent? } \\
\text { Number and identity of shareholders holding more than } 10 \text { per } \\
\text { cent? } \\
\text { Percentage of cross-ownership? } \\
\text { Existence of a Corporate Governance Charter or Code of Best } \\
\text { Practice? } \\
\text { Corporate Governance Charter/Code of Best Practice itself? } \\
\text { Details about its Articles of Association (for example, changes)? } \\
\text { Voting rights for each voting or non-voting share? } \\
\text { Way the shareholders nominate directors to board? } \\
\text { Way shareholders convene an Extraordinary General Meeting } \\
\text { (EGM)? } \\
\text { Procedure for putting enquiry rights to the board? } \\
\text { Procedure for putting proposals at shareholders meetings? } \\
\text { Review of last shareholders meeting (for example, minutes)? }\end{array}$ \\
\hline
\end{tabular}

(Source: Subramaniana and Reddy, 2012) 


\section{REFERENCES}

1. Aggarwal, R., Klapper, L. and Wysocki, P. D. (2005), "Portfolio preferences of foreign institutional investors", Journal of Banking and Finance, Vol. 29, No. 12, pp. 2919-2946.

2. Alpay, G., Bodur, M., Ener, H. and Talug, C. (2005), "Comparing board-level governance at MNEs and local firms: Lessons from Turkey", Journal of International Management, Vol. 11, No. 1, pp. 67-86.

3. Baker, H. K., Nofsinger, J. R. and Weaver, D. G. (2002), "International cross-listing and visibility", Journal of Financial and Quantitative Analysis, Vol. 37, No. 3, pp. 495-521.

4. Beekes, W. and Brown, P. (2006), "Do better-governed Australian firms make more informative disclosures?", Journal of Business Finance \& Accounting, Vol. 33, No. 3/4, pp. 422-450.

5. Bell, R. G., Filatotchev, I. and Rasheed, A. A. (2012), "The liability of foreignness in capital markets: Sources and remedies", Journal of International Business Studies, Vol. 43, No. 2, pp. 107-122.

6. Bhattacharyya, A. K. and Rao, S. V. (2004), "Economic impact of 'regulation on corporate governance': Evidence from India”, No. 486. Working Paper.

7. Black, B. S. and Khanna, V. S. (2007), "Can corporate governance reforms increase firm market values? Event study evidence from India", Journal of Empirical Legal Studies, Vol. 4, No. 4, pp. 749-796.

8. Botosan, C. A. (1997), "Disclosure level and the cost of equity capital", The Accounting Review, Vol. 72, No. 3, pp. 323-349.

9. Botosan, C. A. and Plumlee, M. A. (2002), "Re-examination of disclosure level and the expected cost of equity capital", Journal of Accounting Research, Vol. 40, No. 1, pp. 21-40.

10. Bouquet, C. and Birkinshaw, J. (2008), "Managing power in multinational corporation: How low power actors gain influence", Journal of Management, Vol. 34, No. 3, pp. 477-508.

11. Bushman, R.M., Piotroski, J.D. and Smith, A.J. (2004), "What determines corporate transparency?", Journal of Accounting Research, Vol. 42, No. 2, pp. 207-252.

12. Choi, F. D. S. and Mueller, G. G. (1996), International Accounting. $2^{\text {nd }}$ ed. Englewood Cliffs, N.J.: Prentice-Hall.

13. Citi Depositary Receipts Year-End 2011 Report, January 2012.

14. Coffee Jr, J. C. (2007), "Law and the market: the impact of enforcement", University of Pennsylvania Law Review, Vol. 156, No. 2, pp. 229-311.

15. Coffee Jr, J. C. (1999), "The future as history: The prospects for global convergence in corporate governance and its implications", Northwestern University Law Review, Vol. 93, pp. 641-708.

16. Cooke, T. E. (1989a), "Disclosure in the corporate annual reports of Swedish companies", Accounting \& Business Research, Vol. 19, No. 74, pp. 113-124.

17. Cooke, T. E. (1989b), "Voluntary corporate disclosure by Swedish companies", Journal of International Financial Management \& Accounting, Vol. 1, No. 2, pp. 171-195.

18. Crawford, E. P. and Williams, C. C. (2010), "Should corporate social reporting be voluntary or mandatory? Evidence from the banking sector in France and the United States", Corporate Governance, Vol. 10, No. 4, pp. 512-526.

19. Dacin, M. T., Kostova, T. and Roth, K. (2008), "Institutional theory in the study of multinational corporations: A critique and new directions", Academy of Management 
Review, Vol. 33, No. 4, pp. 994-1006.

20. Dey, A, (2005), "Corporate governance and financial reporting credibility”, Doctoral Dissertation, Northwestern University, UMI. 3177709.

21. Dharmapala, D. and Khanna, V. (2013), "Corporate governance, enforcement, and firm value: Evidence from India", Journal of Law, Economics, and Organization, Vol. 29, No. 5, pp. 1056-1084.

22. Doidge, C., Karolyi, G. A. and Stulz, R. M. (2010), "Why do foreign firms leave US equity markets?", The Journal of Finance, Vol. 65, No. 4, pp. 1507-1553.

23. Doidge, C., Karolyi, G. A. and Stulz, R. M. (2007), "Has New York become less competitive global markets? evaluating foreign listing choices over time." NBER Working Paper Series, No. 13079, May, pp. 1-65.

24. Doidge, C., Karolyi, G. A. and Stulz, R. M. (2004), "Why are foreign firms listed in the US worth more?", Journal of Financial Economics, Vol. 71, No. 2, pp. 205-238.

25. Errunza, V. R. and Miller, D. P. (2000), "Market segmentation and the cost of the capital in international equity markets", Journal of Financial and Quantitative analysis, Vol. 35, No. 4, pp. 577-600.

26. Ferreira, M. A. and Matos, P. (2008), "The colors of investors' money: the role of institutional investors around the world", Journal of Financial Economics, Vol. 88, No. 3, pp. 499-533.

27. Foerster, S. R. and Karolyi, G. A. (1999), "The effects of market segmentation and investor recognition on asset prices: evidence from foreign stocks listing in the United States", Journal of Finance, Vol. 54, No. 3, pp. 981-1013.

28. Francis, J., Khurana, I. and Pereira, R. (2005), "Disclosure incentives and effects of cost of capital around the world", The Accounting Review, Vol. 80, No. 4, pp. 11251162.

29. Hail, L. and Leuz, C. (2009), "Cost of capital effects and changes in growth expectations around US cross-listings", Journal of Financial Economics, Vol. 93, No. 3 , pp. 428-454.

30. Healy, P. M., Hutton, A. P. and Palepu, K. G. (1999), "Stock performance and intermediation changes surrounding sustained increases in disclosure", Contemporary Accounting Research, Vol. 16, No. 3, pp. 485-520.

31. Hope, O. K. (2003a), "Disclosure practices, enforcement of accounting standards, and analysts' forecast accuracy: an international study", Journal of Accounting Research, Vol. 41, No. 2, pp. 235-272.

32. Hope, O. K. (2003b), "Firm-level disclosures and the relative roles of culture and legal origin", Journal of International Financial Management and Accounting, Vol. 14, No. 3, pp. 218-248.

33. Jaggi, B. and Low, P. Y. (2000), "Impact of culture, market forces, and the legal system on financial disclosures", International Journal of Accounting, Vol. 35, No. 4, pp. 495-519.

34. Jithendranathan, T., Nirmalanandan, T. R. and Tandon, K. (2000), "Barriers to international investing and market segmentation: evidence from Indian GDR market", Pacific-Basin Finance Journal, Vol. 8, No. 3, pp. 399-417.

35. Kamran, A. and Nicholls, D. (1994), "The impact of non-financial company characteristics on mandatory disclosure in developing countries: the case of Bangladesh", International Journal of Accounting Education and Research, Vol. 29, No. 1, pp. 62-77.

36. Karolyi, G. A. (2012), "Corporate Governance, Agency Problems and International Cross-Listings: A Defense of the Bonding Hypothesis", Emerging Markets Review, Vol. 13, No. 4, pp. 516-547 
37. Karolyi, G. A. (2006), "The world of cross-listings and cross-listings of the world: challenging conventional wisdom", Review of Finance, Vol. 10, No. 1, pp. 99-152.

38. Karolyi, G. A. (1998), "Why do companies list shares abroad?: a survey of the evidence and its managerial implications", Financial Markets, Institutions and Instruments, Vol. 7, No. 1, pp. 1-60.

39. Khanna, V.S. (2008), The anatomy of corporate governance reform in an emerging market: The case of India. Working Paper.

40. Khanna, T., Palepu, K. G. and Srinivasan, S. (2004), "Disclosure practices of foreign companies interacting with US markets", Journal of Accounting Research, Vol. 42, No. 2, pp. 475-508.

41. Kiel, G. C., Hendry, K. and Nicholson, G.V. (2006), "Corporate governance options for the local subsidiaries of multinational enterprises", Corporate Governance: An International Review, Vol. 14, No. 6, pp. 568-576.

42. Kostova, T. and Roth, K. (2002), "Adoption of an organizational practice by subsidiaries of multinational corporations: institutional and relational effects", Academy of Management Journal, Vol. 45, No. 1, pp. 215-233.

43. Kostova, T. and Zaheer, S. (1999), "Organizational legitimacy under conditions of complexity: the case of multinational enterprise", Academy of Management Review, Vol. 24, No. 1, pp. 64-81.

44. Krigger, M.P. (1988), "The increasing role of subsidiary boards in MNCs: an empirical study", Strategic Management Journal, Vol. 9, No. 4, pp. 347-360.

45. Lang, M. H., Lins, K. V. and Miller, D. P. (2004), "Concentrated control, analyst following, and valuation: do analysts matter most when investors are protected least?", Journal of Accounting Research, Vol. 42, No. 3, pp. 589-623.

46. Lang, M. H., Lins, K.V. and Miller, D.P. (2003a), “ADRs, analysts and accuracy: does cross listing in the United States improve a firm's information environment and increase market value?", Journal of Accounting Research, Vol. 41, No. 2, pp. 317345.

47. Lang, M. H., Raedy, J.S. and Yetman, M. (2003b), "How representative are firms that are cross-listed in the United States? an analysis of accounting quality", Journal of Accounting Research, Vol. 41, No. 2, pp. 363-396.

48. La Porta, R., Lopez-de-Silanes, F. and Shleifer, A. (1999), "Corporate ownership around the world", Journal of Finance, Vol. 54, No. 2, pp. 471-517.

49. La Porta, R., Lopez-de-Silanes, F., Shleifer, A. and Vishny, R. W. (1998), "Law and finance". Journal of Political Economy, Vol. 106, No. 6, pp. 1113-1155.

50. Leksell, L. and Lindgren, U. (1982), "The board of directors in foreign subsidiaries", Journal of International Business Studies, Vol. 13, No. 1, pp. 27-38.

51. Leuz, C. (2003), "Discussion of ADRs, analysts, and accuracy: does cross listing in the United States improve a firm's information environment and increase market value?", Journal of Accounting Research, Vol. 41, No. 2, pp. 347-362.

52. Leuz, C. and Verrecchia, R. E. (2000), "The economic consequences of increased disclosure", Journal of Accounting Research, Vol. 38, pp. 91-124.

53. Lev, B. (1992), "Information disclosure strategy", California Management Review, Vol. 34, No. 4, pp. 9-32.

54. Lins, K. V., Strickland, D. and Zenner, M. (2005), "Do non-US firms issue equity on US stock exchanges to relax capital constraints?", Journal of financial and quantitative analysis, Vol. 40, No. 1, pp. 109-133.

55. Loughran, T. and Ritter, J.R. (1995), “The new issues puzzle”, Journal of Finance, Vol. 50, No. 1, pp. 23-51. 
56. Luo, Y. (2005), "Corporate governance and accountability in multinational enterprises: concepts and agenda", Journal of International Management, Vol. 11, No. 1, pp. 1-18.

57. Madhani, P. M. (2015), "MNC Subsidiaries vs Domestic Firms", SCMS Journal of Indian Management, Vol. 12, No. 1, pp. 5-24.

58. Madhani, P. M. (2014), "Corporate governance and disclosure practices in India: Domestic firms versus cross-listed firms", The IUP Journal of Corporate Governance, Vol. 13, No. 4, pp. 24-51.

59. Madhani, P. M. (2007), "Corporate governance from compliance to competitive advantage", The Accounting World, Vol. 7, No. 8, pp. 26-31.

60. Marston, C. L. and Shrives, P. J. (1991), "The use of disclosure indices in accounting research: a review article", The British Accounting Review, Vol. 23, No. 3, pp. 195210.

61. Mohanty, P. (2003), "Institutional investors and corporate governance in India", National Stock Exchange of India Research Initiative Paper No. 15. http://ssrn.com/abstract=353820.

62. Nair, S. and Skaggs, B. C. (2012), "Performance implications of cross-listing for emerging vs. developed market firms: an institutional legitimacy approach", International Journal of Business and Emerging Markets, Vol. 4, No. 3, pp. 223-240.

63. Oxelheim, L. and Randøy, T. (2003), "The impact of foreign board membership on firm value", Journal of Banking \& Finance, Vol. 27, No. 12, pp. 2369-2392.

64. Pattnaik, C. and Gray, S. (2012), "Differences in corporate transparency between MNC subsidiaries and domestic corporations: empirical evidence from India", Transparency and Governance in a Global World, Vol.13, pp.173-196.

65. Peng, M. W. and Blevins, D. (2012), "Why do Chinese firms cross-list in the United States?" In A. A. Rasheed and T. Yoshikawa (Eds.), The Convergence of Corporate Governance: Promises and Prospects (pp. 249-265). New York: Palgrave Macmillan.

66. Peng, M. W. and Su, W. (2014), "Cross-listing and the scope of the firm", Journal of World Business, Vol. 49, No. 1, pp. 42-50.

67. Puthenpurackal, J. (2006), "Explaining premiums in restricted DR markets and their implications: the case of Infosys", Financial Management, Vol. 35, No. 2, pp. 93-116.

68. Reese Jr, W. A. and Weisbach, M. S. (2002), "Protection of minority shareholder interests, cross-listings in the United States, and subsequent equity offerings", Journal of Financial Economics, Vol. 66, No. 1, pp. 65-104.

69. Rosenzweig, P. M. and Singh, J.V. (1991), "Organizational environments and the multinational enterprise", Academy of Management Review, Vol. 16, No. 2, pp. 340361.

70. Roth, K. and Kostova, T. (2003), “Organizational coping with institutional upheaval in transition economies", Journal of World Business, Vol. 38, No. 4, pp. 314-330.

71. Sanan, N. (2011), "Corporate governance in public and private sector enterprises: evidence from India", The IUP Journal of Corporate Governance, Vol. 10, No. 4, pp. 37-59.

72. Sapovadia V. K. (2011), "Corporate governance index vis-à-vis value distribution analysis." http://ssrn.com/abstract=1752004, pp. 1-37.

73. Sarkar, S. and Sarkar, J. (2000), "Large shareholder activism in corporate governance in developing countries: Evidence from India", International Review of Finance, Vol. 1, No. 3, pp. 161-194.

74. Sengupta, P. (1998), "Corporate disclosure quality and the cost of debt", The Accounting Review, Vol. 73, No. 4, pp. 459-474. 
75. Shi, Y., Magnan, M. and Kim, J. B. (2012), "Do countries matter for voluntary disclosure? evidence from cross-listed firms in the US", Journal of International Business Studies, Vol. 43, No. 2, pp. 143-165.

76. Siegel, J.I. (2009), "Is there a better commitment mechanism than cross-listings for emerging economy firms? evidence from Mexico", Journal of International Business Studies, Vol. 40, No. 7, pp. 1171-1191.

77. Siegel, J. I. (2005),'Can foreign firms bond themselves effectively by renting U.S. securities laws?", Journal of Financial Economics, Vol. 75, No. 2, pp. 319-359.

78. Sinha, R. (2006), "Corporate governance and shareholder value analysis", Global Business Review, Vol. 7, No. 1, pp. 1-16.

79. Srinivasan, P. (2008), "Analysis of factors influencing corporate voluntary disclosure practices", In P. M. Madhani (Ed). Corporate Disclosure: Concepts and Practices, Hyderabad: ICFAI University Press.

80. Stulz, R. M. (1999), "Globalization, corporate finance, and the cost of capital", Journal of Applied Corporate Finance, Vol. 12, No. 3, pp. 8-25.

81. Subramaniana, S. and Reddy, V. N. (2012), "Corporate governance disclosures and international competitiveness: a study of Indian firms", Asian Business \& Management, Vol. 11, No. 2, pp. 195-218.

82. Volkmar, J. A. (2003), "Context and control in foreign subsidiaries: making a case for the host country national manager", Journal of Leadership \& Organizational Studies, Vol. 10, No. 1, pp. 93-105.

83. Westney, D. E. (2005), "Institutional theory and the multinational corporation", In S. Ghoshal, and D. E. Westney (Eds.), Organization Theory and the Multinational Corporation. New York: Palgrave Macmillan.

84. Williams, C. (2009). Subsidiary-level determinants of global initiatives in multinational corporations. Journal of International Management, Vol. 15, No. 1, pp. 92-104.

85. World Bank Report (2005), India: Role of Institutional Investors in the Corporate Governance of their Portfolio Companies. 